\title{
TIMELY DETERMINING AND PREVENTING CONFLICT SITUATIONS BETWEEN INVESTORS AND THIRD PARTIES: SOME OBSERVATIONS FROM LITHUANIA
}

\author{
Olga Regina S̆OSTAK $1 \bowtie$ and Daiva MAKUTÉNIENE் ${ }^{2}$ \\ ${ }^{1}$ Faculty of Fundamental Sciences, Vilnius Gediminas Technical University, Sauletekio ave. \\ 11, LT-10223 Vilnius, Lithuania \\ E-mail: olga-regina.sostak@vgtu.lt \\ ${ }^{2}$ Faculty of Fundamental Sciences, Vilnius Gediminas Technical University, Sauletekio ave. \\ 11, LT-10223 Vilnius, Lithuania
}

Received 15 November 2011; accepted 7 March 2012

\begin{abstract}
The article analyses the possible influence of third-party rights infringed during construction planning on the implementation of an investment project. It analyses the process for defence of third party rights infringed during territorial planning. The focus in this process is on third party rights and opportunities to learn about possible infringement of such rights. In a construction project, judicial disputes are an unwanted risk factor, which may disrupt the entire project. It is therefore necessary to plan and apply preventive measures for the mitigation of such risk at the initial planning stage of a construction project. For that end, the article presents some principles of behaviour and actions that could help investors and third parties to solve conflicts, reduce their negative outcomes or reach an arrangement satisfactory to both disputing parties.
\end{abstract}

KEYWORDS: Construction investment process; Judicial defence of third-party rights; Collaboration; Determination and management of conflict situations; Negotiations with stakeholder groups

REFERENCE to this paper should be made as follows: Šostak, O. R. and Makutenienè, D. (2013) Timely determining and preventing conflict situations between investors and third parties: some observations from Lithuania, International Journal of Strategic Property Management, 17(4), pp. 390-404.

\section{INTRODUCTION}

In most of our cities, some parts undergo intensive transformations related to commercialisation, land use and the density of buildings (Kaklauskas et al., 2007; Bardauskienè, 2007; Banaitis and Banaitienè, 2007). Several examples in European cities show that development can embrace internal urban areas (Erdis, 2013). Currently, Lithuanian cities also witness concentrated development (Burinskienè,
2009; Jakaitis et al., 2009; Zavadskas et al., 2010b; Kaklauskas et al., 2009). It allows using the existing infrastructure and abandoned urban territories. Such planning also reduces the amount of used land and creates a lasting environment, the immensely dense population of which is not always able to function properly (Burinskienè and Rudzkienè, 2009). On one hand, it is a natural stage related to the 
renovation of neglected valuable urban areas. On the other hand, the course and outcomes at this stage reveal gaps within the renewal process. We are inclined to blame the drawbacks of laws regulating urban planning and protection of visual identity (investors cannot always be expected to abandon their self-centred ends for the sake of urban values, etc.) (McDonald et al., 2009). This is largely influenced by a confusing, non-effective system for the coordination of constructions with government institutions and the public. The regulation of constructions is confusing; builders breach the introduced requirements; officials are frequently provided with the right to easily choose the requirements necessary to be applied (Šostak and Vakrinienè, 2011; Mitkus and Šostak, 2008; Šstak, 2011). An inappropriate distribution of functions among government institutions and private subjects raise a number of problems. One of the outcomes of inappropriate legal regulation is the violation of the third-party rights (i.e. the parties not directly related to the construction investment process: the owners of neighbouring plots, users, communities of residential districts, etc.).
The legislator defines the public concerned as the public affected or likely to be affected by the solutions of the territorial planning document being prepared (The Law on Territorial Planning of the Republic of Lithuania, 2004). In order to determine possible actions of persons involved in detailed planning - the process which might infringe third party rights it is important to know the parties involved in territorial planning.

The classification of parties involved in territorial planning is shown in Figure 1. The following persons participate in territorial planning:

1. Planners;

2. Organisers of planning;

3. Territorial planning supervisory bodies; and

4. Third parties.

Third parties are the most sensitive group, because they are not participating in territorial planning directly but their rights may be infringed at any phase of detailed planning. As a result, disputes may arise between persons participating in territorial planning and some of the disputes may reach the court. Of-
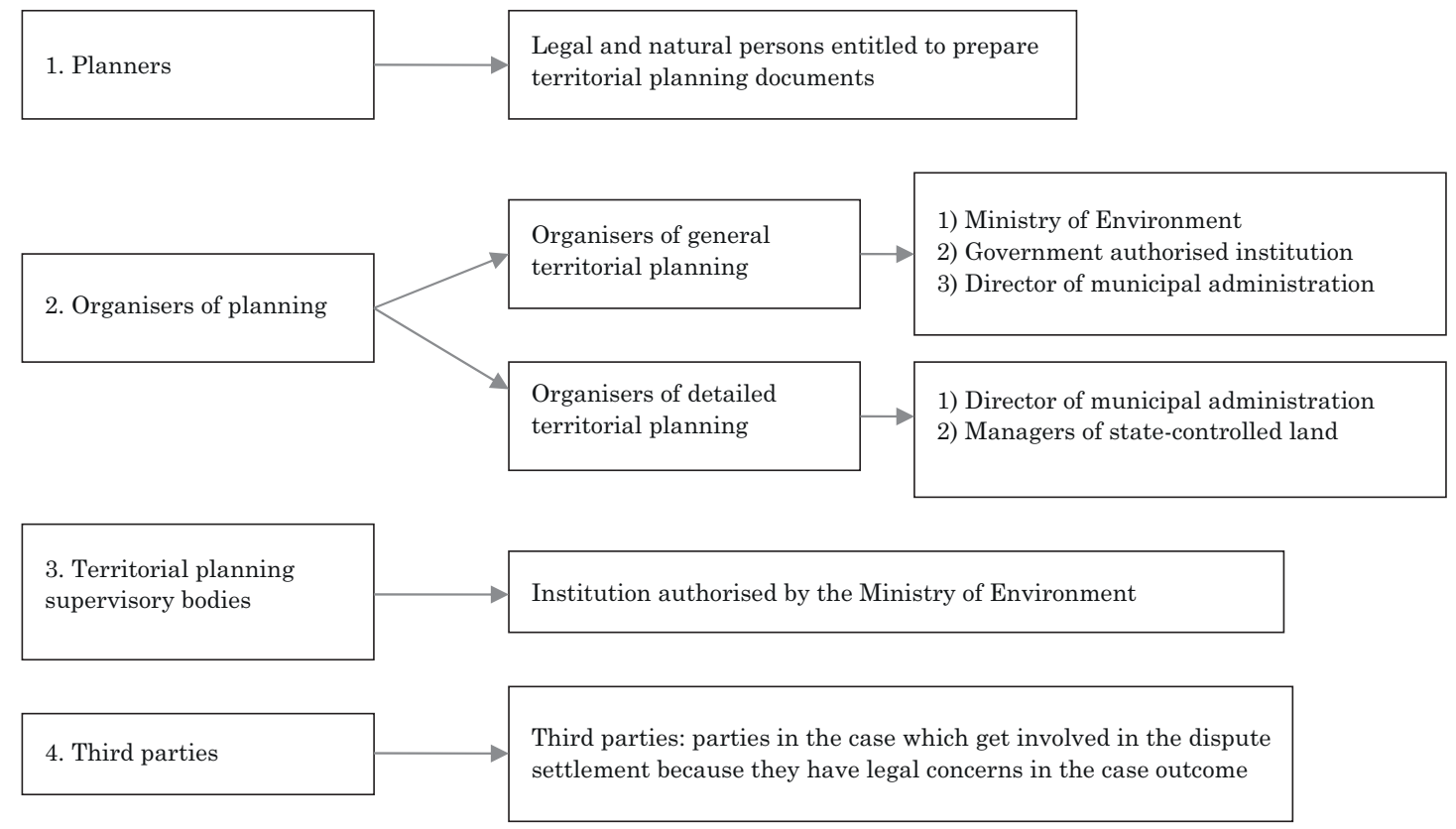

Figure 1. Classification of parties involved in territorial planning 
ten, such disputes mean additional costs for both parties. Even the winning party in a legal dispute may often incur loss (construction suspension during the judicial dispute, lawyer fees, etc.). Violations of third-party rights are of benefit neither to third parties, nor to the parties of the investment process, because, on one hand, such violations might wrongfully cause the deterioration of the conditions for life and other activities of third persons. On the other hand, violations of third-party rights at the stage of construction planning may affect the implementation of the investment project, because all solutions violating third-party rights also violate the provisions of legal acts and can be disputed as stipulated by the Law on Administrative Proceedings of the Republic of Lithuania (2004), the Law on Territorial Planning of the Republic of Lithuania (2004) and other legal acts (Šostak and Vakrinienè, 2011; Mitkus and Šostak, 2008).

The article analyses the influence of thirdparty rights infringed during construction planning on the implementation of an investment project, ways to prevent conflict situations with the public concerned and the necessary conflict-settlement actions on the part of the investor in order to lead any conflict in positive direction and go through with the construction investment project successfully.

The development of the national economy is impossible without construction: people use construction products - various buildings - to live, work and satisfy other social needs. Construction investment contributes to national economic growth and development extensively (Zavadskas and Kaklauskas, 2008; Zavadskas et al., 2009; Medineckiene et al., 2010; Lopes et al., 2011). The investment process in construction is long and complicated; it requires enormous financial, intellectual and other resources. If judicial disputes occur during this process, the investor may incur huge loss, and project implementation may be postponed for an indefinite term. Litigation may continue for several years (The Supreme Administrative Court of Lithuania, 2007a; The Supreme Administrative Court of Lithuania, 2007b). Thus investors are most concerned to avoid any legal disputes and should pay considerable attention to their prevention.

In a construction project, judicial disputes are an unwanted risk factor, which may disrupt the entire project (Park et al., 2009; Pinter and Pšunder 2013). It is therefore necessary to plan and apply preventive measures for the mitigation of such risk at the initial planning stage of a construction project. To evaluate and eliminate these risk factors, state-of-theart technologies for construction project planning and management must be integrated into each step of construction project planning and implementation. It is necessary to employ innovative methods for construction project planning and implementation when the conditions are indeterminate (Kahraman and Kaya, 2010; Blaszczyk and Nowak, 2009). Risk management strategies and the development of a risk management plan must be improved, risk analysis methods and technologies must be used, and the risk reporting mechanism must be implemented. For a successful construction project, it is worth to employ the functions of project management. It is necessary to analyse the risk using the knowledge of relevant experts and to properly evaluate the scope of possible negative effects and their outcomes to the construction project. The findings should influence the subsequent decision-making process (Desierto, 2013; Chou and Lin, 2013; Chamodrakas et al., 2011; Antuchevičienè et al., 2010; Zavadskas and Turskis, 2011; Banaitienè et al., 2011; Xu et al., 2012). Risks must be monitored and decision-making must be analysed throughout the project lifecycle. Before launching a project, an investor must be ready for any "surprises". Forecasting is the most important part of any strategy, because the actions recommended for certain situations stem from the forecasts of possible outcomes. The lessons about risk management learned during implementation of construction projects should be used in future projects (Zavadskas et al., 2010a; Yang et al., 2009; Šostak and Vakrinienè, 2011; Lin et al., 2011; Yeh et al., 2012; Witt and Liias, 2011). 
If a judicial dispute occurs when the construction project has already been launched, the investor must also consider all possible actions of judicial institutions. Thus investors must be aware of the defence procedures in administrative courts when third-party rights are violated during the territorial planning they must consider possible actions of third parties.

A conflict situation may spring up at any stage of a construction investment project. Constructive or destructive development of a conflict generally depends on the investor's behaviour (Dixon, 1996; Ramirez, 1999). Disrespectful and provocative behaviour of the investor may encourage third parties to fight and oppose. It is in the interests of any investor to suppress a conflict right at its beginning. The investor thus must be able to communicate with the opponent (the public opposing the construction), to exchange relevant information and make use of other conflict-settlement actions. We shall discuss them in the next chapter.

\section{DETERMINING THE CAUSES CONTRIBUTING TO THE DESTRUCTIVE DEVELOPMENT OF CONFLICT SITUATIONS BETWEEN THE INVESTOR AND THIRD PARTIES CAUSED BY ALLEGEDLY INFRINGED THIRD-PARTY RIGHTS}

The analysis of the procedure related to the defence of violated third-party rights in administrative courts leads to the conclusion that a judicial dispute may either ruin a construction investment project completely or cut the expected profits considerably. Largely, it depends on the decisions of the communities concerned (third persons) opposing the construction and on the decisions of judicial institutions hearing the disputes. Naturally, investors are most interested to avoid any legal disputes. A possible preventive measure to mitigate such risk is assessment and proper analysis of all possible future events related to the occurrence of such risk before launching the investment project.
For that purpose, the investor must come up with scenarios of actions in probable situations and plan the strategic options. The investor, most interested to avoid any legal disputes, should assess all possible risk factors that may affect the implementation of a construction project. Strategies must be prepared which can help to handle and control a large portion of conflicts. The interests and goals of the investor and third parties, the circumstances and factors affecting their activities, and the course of their actions must be analysed.

In this instance, conflict handling is attributed to positive attitude of, and rational collaboration between, the investor and the public concerned. The parties in conflict must admit and understand different, often opposite, needs and interests and make joint efforts to find possible solutions. The basis of conflict handling is the determination to collaborate. Collaboration is interaction of two or more social entities towards certain goals - generally shared, but often different or even opposite (Lakis, 2008; Smyth, 2002).

A conflict reveals a problem in the status quo. A conflict brings confusion to the status quo, but also forces its critical assessment and initiation of changes in order to bring about a more advantageous situation than before. One must consistently seek constructive aspects in any conflict. In real-life cases, unfortunately, the conflicting parties sometimes fail to follow these principles. They often start fighting and the conflict takes a destructive course leading to a complete failure. There are several reasons for this. Say, when one party seeks to communicate and start a discussion in case of a conflict, the other party is more likely to respond with willingness to collaborate. On the contrary, a party responding to aggressive behaviour of the other is generally likely to become defensive or inclined to fight (Lakis, 2008; Keršulienè et al., 2010; Deutsch, 1994). To see the conditions that determine either constructive or destructive course of conflicts, we shall look into a real-life case that reveals the interrelations between conflicting parties, their interests and actions. 
On 21 January 2005 the judicial panel of the Supreme Administrative Court of Lithuania held an open appellative hearing to judge the administrative case based on the appeals of the Administration of Vilnius City Municipality, the defendant, and Eika UAB, a third party concerned, against the judgement of Vilnius County Administrative Court (passed on 30 September 2004) revoking the defendant's order in the administrative case based on the complaint of the Homeowner Association No. 968, the claimant, against the Administration of Vilnius City Municipality, the defendant (The Supreme Administrative Court of Lithuania, 2005).

The judicial panel determined that the Homeowner Association No. 968 applied to court asking to revoke the defendants order No. 01A-66-V-14 of 13 March 2003 approving the solutions of the detailed plan of the territory adjacent to Dainavos Street 1, 3, 3 a and Gedimino Avenue 44. The claimant justifies the complaint on the grounds that the solutions of the detailed plan approved by the order violate the rights of owners and other occupants of the building at Gedimino Avenue 44. The complaint states that the new construction foreseen in the detailed plan will cause the insolation of apartments in the building at Gedimino Avenue 44 drop below the norm. The detailed plan fails to comply with the requirements applicable to the minimum spacing of buildings and thus violates the fire safety requirements; it also fails to foresee the normative sanitary protection zone that must be around the source of pollution - the garage. The detailed plan includes improperly designed access roads to the underground garage and fails to foresee any car parks. The solutions of the detailed plan mean that the house at Gedimino Avenue 44 will no longer have its access road to the yard. A supplement to the complaint points out to the violation of the public discussion procedure required for such detailed plan, because the plan was discussed on 27 November 2002, but coordinated with individual bodies after the discussion. The claimant points out that the detailed plan no longer includes previously foreseen servitudes regulating the site coverage and the height of buildings and fails to comply with the provisions set forth on 27 December 2002 and applicable to general plans, detailed plans and special planning documents (The Supreme Administrative Court of Lithuania, 2005).

The court of first instance stated that, according to Article 20(8) of the then effective version of the Law on Territorial Planning of the Republic of Lithuania (2004), a detailed plan could not be approved if it conflicted with the general plan, or if the prescribed procedure of coordination, public discussion and supervision had been violated, or the solutions of the detailed plan failed to comply with the norms of territorial planning or construction. The violations of public discussion procedures specified by the claimant were determined to be valid. The court pointed out that Clause 23 of the then effective "Regulations for Detail Plans" approved by the order No. 159 of the Minister of Construction and Urban Matters on 15 November 1996 foresaw three stages for preparing detailed plans. Articles 19, 20 and 25 of the then version of the Law on Territorial Planning of the Republic of Lithuania (2004) prescribed certain procedures to each stage: preparation, coordination, public discussion and approval of the detailed plan. A legal analysis of these norms brought to the conclusion that the plan must be submitted for public discussion after it has been coordinated and all designing assignments completed in line with the conditions approved for this particular plan. It was determined that the public discussion of the solutions of the detailed plan approved by the disputed order had been held on 27 November 2002 , but the markings on the main drawing of the detailed plan showed that it had been coordinated with individual professionals after the public discussion. The insolation values were also determined in 2003. Article 20(8) of the then effective version of the Law on Territorial Planning of the Republic of Lithuania (2004) stated that violations of the 
public discussion procedures applicable to the plan rendered its approval impossible. This part of the claim was therefore satisfied and the defendant's order No. 01A-66-V-14 of 13 March 2003, which approved the solutions of the detailed plan of the territory adjacent to Dainava Street 1, 3, 3 a and Gediminas Avenue 44, was annulled as illegal (Article 89, Part 1, Clause 3 of the Law on Administrative Proceedings of the Republic of Lithuania, 2004). Because the order was annulled, the detailed plan was ordered to be resubmitted for public discussion. Before the resubmission all violations proved during the hearing and used as the basis for the annulment had also to be remedied (The Supreme Administrative Court of Lithuania, 2005).

The Administration of Vilnius City Municipality submitted an appeal asking to cancel the judgement of Vilnius County Administrative Court of 30 September 2004 and to pass a new judgement rejecting the complaint. The defendant points out to the fact that legal acts do require public discussion of prepared detailed plans but nowhere specify that the solutions can no longer be coordinated and approved after such discussion. On the contrary, in case there are justified claims or suggestions expressed during the discussion or within a certain term regarding the solutions of the detailed plan, individual solutions can be adjusted and coordinated after the public discussion, notifying the stakeholders hereof. The appellant believes that such narrow interpretation of the detailed planning procedures as suggested by the court would violate the rights of the organiser of detailed planning, because they would impose a liability to repeat the entire public discussion procedure to introduce any new solution, thus protracting territorial planning and going against the principles of rationality and proportionality applicable to planning. The appellant insists that, according to the norms specified in Article 28(1) of the then effective version of the Law on Territorial Planning of the Republic of Lithuania (2004), organisers of planning could, in the prescribed manner, submit for public discussion either the programme of the detailed plan, the goals of the general plan or a ready territorial planning document. It was even allowed to submit for public discussion a draft rather than the final version of the detailed plan (the programme or goals of the detailed plan). Currently, none of the legal acts in force prescribe submission of an already approved detailed plan for public discussion either. The appellant therefore disagrees with the conclusions laid out in the court's judgement and believes that the public discussion procedure has not been violated.

In its response to the appeals, the Homeowner Association No. 968 refuses to accept the requirements set forth in the appeals. The association insists that the order of the director of the Administration of Vilnius City Municipality basically approved a new detailed plan, not the one that had been discussed with the public. Such conclusion can be drawn seeing the differences between two variants of the plans presented in the claimants complaint and the supplement thereof (the approved detailed plan no longer had the access to the yard, the servitudes regulating the site coverage and the height of buildings, which must be one storey; it also eliminated classification of territories into two types).

The judicial panel states that the appeals of the Administration of Vilnius City Municipality, the defendant, and Eika UAB, a thirdparty stakeholder, have been rejected and the judgement of Vilnius County Administrative Court of 30 September 2004 remains in force unaltered. The judicial panel came to such procedural decision after stating that the court of first instance made proper analysis of the circumstances relevant to dispute settlement, made proper construction and use of the law and therefore there is no basis to cancel the judgement appealed against. No material violations of the procedural law constituting a basis to cancel the judgement have been determined in the appellative hearing. The arguments provided in the appeals of the appellants are unjustified and must be rejected.

The judicial panel explains the public discussion procedure. The appellants' statement 
that modification of the solutions of their detailed plan after the public discussion procedure is legal contradicts the legal norms which regulate the legal relations in a dispute. Article 20(4) of the Law on Territorial Planning of the Republic of Lithuania (2004) version, which was effective when the detailed plan specified in the complaint was being prepared and approved, stated that the detailed plans must be submitted for approval after they had been coordinated, discussed in public and inspected in line with the prescribed procedures. Article 23 "General Procedure for Co-ordinating and Presenting for Approval Territorial Planning Documents" of the law set forth the mandatory sequence of these procedures even more explicitly and stated that "prior to their presentation for approval, solutions of general, special and detailed territorial planning documents must be:

1. Co-ordinated with the effective territorial planning documents of the appropriate level or have a written approval of appropriate bodies;

2. Discussed in public;

3. Inspected by the territorial planning supervisory body".

Part 4 of the same Article set forth the imperative requirement to coordinate, discuss in public and approve - in the prescribed manner - any changes of the planning documents introduced because of coordination activities. Article 27 of the then version of the Law on Territorial Planning of the Republic of Lithuania (2004) specified that any suggestions and claims regarding the detailed plan may be submitted only prior to the public meeting and must be discussed in such meeting; initiators of suggestions or claims rejected during the public discussion have one month to appeal against the solutions of the planning documents in line with the procedure prescribed by the law. The construction of the provisions set forth in the Law on Territorial Planning of the Republic of Lithuania (2004) suggested by the appellants would negate the point of the public discussion procedure, which is to guarantee an opportunity for the public and stakeholders to take part in preparation of the detailed plan and to have a say in this process so as to prevent infringements of their rights and interests protected by the law. This case determined that part of the solutions of the detailed plan had been changed and coordinated after the public discussion procedure and thus deprived stakeholders and representatives of the public to have a say in their approval or rejection. The court of first instance made a justified decision that this violation of the public discussion procedure prescribed by the law was related to the basis set forth in Article 20(8) of the then effective version of the Law on Territorial Planning of the Republic of Lithuania (2004), which rendered approval of the detailed plan impossible. This circumstance forms an independent basis to annul the disputed order of the defendant. In view of the specified circumstances, the judicial panel recognises as valid the statement of the court of first instance that the disputed detailed plan is faulty in substance and its solutions fail to comply with the construction norms, which is a relevant basis to annul the disputed administrative act (The Supreme Administrative Court of Lithuania, 2005).

To sum up, public presentation of, and stakeholder consent for, a project is mandatory in line with the laws in force. It might be said that this condition was satisfied during the attempts to legalise the idea: the public concerned had been properly informed about the detailed plan and the project had been discussed with and approved by the public concerned. But part of the solutions of the detailed plan were later changed and coordinated after the public discussion procedure thus depriving the stakeholders and the representatives of the public of an opportunity to influence their approval or rejection. Such actions on the part of the organiser of planning caused the dissatisfaction and protest of the public concerned. The conflict was sparked by the disrespect shown towards the occupants living in the neighbourhood: they were not invited to 
discuss things and the organiser of planning had no intentions to consider the needs of the public concerned. Instead, the project promoters cheated the public concerned into giving its approval and expected to implement the construction investment project successfully. Such behaviour made collaboration impossible and the conflict reached the court. The investor has utmost interest to avoid a judicial dispute, because it means the conflict is hardly manageable and the investor might suffer huge financial loss or the project might be postponed for an indefinite term. In this particular case, the court determined that the detailed plan, which violated the public discussion procedures, could not be approved and pronounced it void. The court stated that annulment of the order meant that the detailed plan must be resubmitted for public discussion. It was also ordered to remedy all violations proved during the hearing and used as the basis for the annulment of the order before the resubmission.

The investor has never gone ahead with the project and the detailed plan has never been resubmitted for public discussion. Unfortunately, this case is not the only pessimistic example in the judicial practice of the Republic of Lithuania (The Supreme Administrative Court of Lithuania, 2006; The Supreme Administrative Court of Lithuania, 2007a; The Supreme Administrative Court of Lithuania, 2007b). Such problems must therefore be thoroughly analysed and possible solutions developed.

The investor's activities were directly related to the interests of the public concerned. Attempts to avoid collaboration with the occupants living in the neighbourhood only meant defeat. To safeguard success of a construction investment project, all potential issues related to stakeholder groups must be determined and sorted out as early as the phase of detailed territorial planning. Open and patient attempts to identify the needs of the public concerned are necessary. Collaboration is required: with open dialogue and negotiations, if necessary. Attempts to negotiate with stakeholder groups are generally made only when the public concerned joins efforts and defends its interests by protesting. In such case, however, negotiations cannot turn into collaboration, because they are done by ultimatums, competition and similar means, which might escalate the conflict further. If the organiser of planning had resolution and professionalism enough to make the first step towards negotiations with stakeholder groups, was not inclined to evade direct relations, was to assess and consider the interests of another party, was to seek compromises, such collaboration could very well turn into partnership. All problems would be handled before the approval of the detailed plan, the investor would escape judicial disputes and construction investment projects would be implemented successfully.

The next chapter will analyse and explain the procedures that ensure publicity in the Republic of Lithuania, because the mistakes made at this stage can hurt implementation of a construction investment project. It is at this stage that democratic actions of the organiser of planning nurture the buds of collaboration with the public concerned.

\section{DETERMINING AND APPLYING THE MEASURES TO PREVENT CONFLICT SITUATIONS BETWEEN THE INVESTOR AND THIRD PARTIES CAUSED BY THIRD-PARTY RIGHTS ALLEGEDLY VIOLATED DURING PREPARATION OF DETAILED PLANS AND IMPLEMENTATION OF THEIR SOLUTIONS}

Violations of third-party rights are of benefit neither to third persons, nor to the parties of the construction investment process, because, on one hand, such violations might wrongfully cause the deterioration of the conditions for life and other activities of third persons. On the other hand, violations of third-party rights at the stage of construction planning may affect the implementation of the investment project, because all solutions violating third-party rights also violate the provisions of legal acts and can be disputed as stipulated by the Law 
on Administrative Proceedings of the Republic of Lithuania (2004), the Law on Territorial Planning of the Republic of Lithuania (2004) and other legal acts (Mitkus and Šostak, 2008; Šostak and Vakrinienè, 2011).

Looking into a unique course of a specific conflict, we relate it to the behaviour and activities of people. Conflict solving and management demands for an analytic approach to a specific conflict: the circumstances behind the conflict and the actions of conflicting parties (in this case, the public concerned - i.e. third parties - and the investor) must be thoroughly analysed. The parties must be ready for decisive actions and inclined to solve problems, disputes and conflicts by joint efforts, in line with laws and other legal measures and using their internal moral capacity, rather than by fighting, cheating or otherwise bypassing other parties concerned (Lakis, 2008). For this reason, it is advisable for the participants of a construction investment process, as well as the third parties, to discuss the ways and the process to protect the third-party rights. Detailed territorial planning approves the basic solutions of a construction investment project.

The defence process of any third-party rights violated during territorial planning may be divided into the following main stages (see Figure 2):

CONSTRUCTIVE DISPUTE-SOLVING SCENARIO

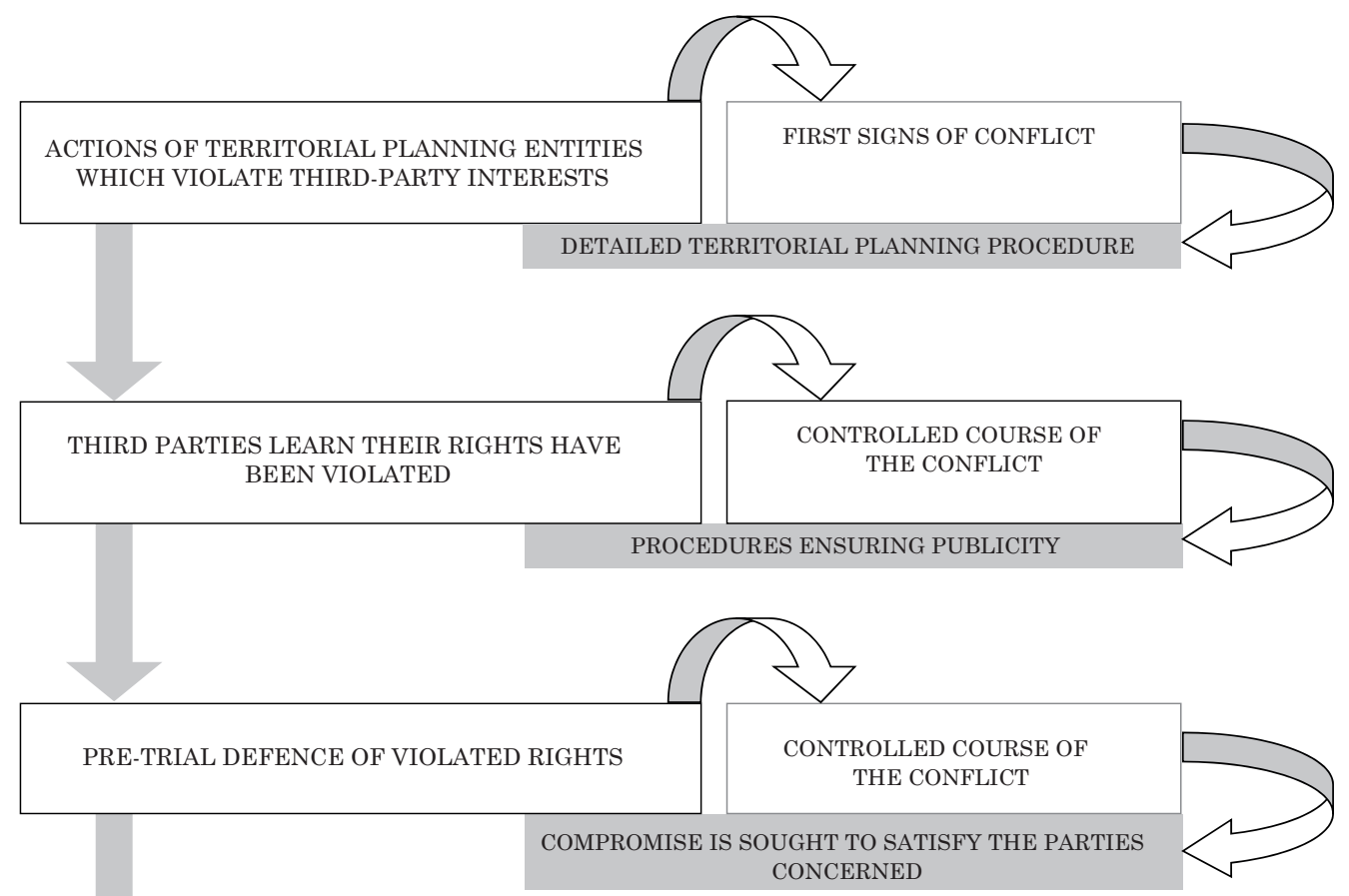

DESTRUCTIVE DISPUTE-SOLVING SCENARIO

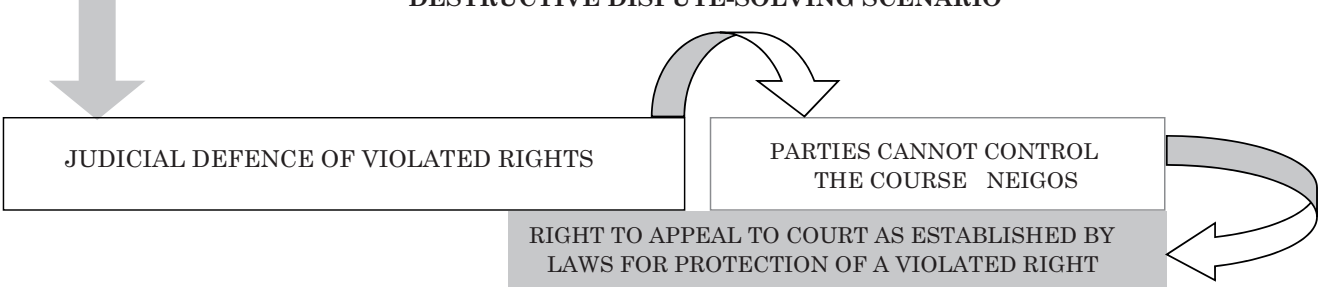

Figure 2. Conflict-solving continuum among entities involved in detailed territorial planning 
1. Actions of the parties involved in territorial planning (inaction, in some cases) against the interests of the third parties;

2. The third parties become aware of the violation;

3. Pre-trial defence of violated rights;

4. Judicial defence of violated rights.

In order to find and select rational ways to protect third-party rights it is necessary to discuss each of the abovementioned stages separately and determine their interrelations.

The first stage of violations of third-party rights during territorial planning is the actions of the parties involved in territorial planning (inaction, in some cases) against the interests of the third parties.

Before commencing with the detailed planning documents, the organiser of planning must apply to the chief architect of the municipality, a civil servant of the municipal administration, for the planning conditions.

The planning conditions are the requirements setting forth special land-use conditions, territorial planning norms, and the solutions of the effective territorial planning documents applicable to the territory to be planned; they also include the provisions set forth in individual sector development programmes and strategic documents, and the requirements on preparation of territorial planning documents enforced by the institutions setting the conditions (The Law on Territorial Planning of the Republic of Lithuania, 2004: Art. 2, 20). In other words, these requirements are mandatory to originators of detailed plans. Originators of detailed plans must comply with both the planning conditions and the requirements of normative legal acts. The digest of planning conditions is the list of planning conditions approved by the chief architect of the municipality, a civil servant of municipality administration, for preparing the territorial planning document and the planning conditions (The Law on Territorial Planning of the Republic of Lithuania, 2004: Art. 2, 21).

The entire pool of planning conditions may be divided into such groups (see Figure 3):

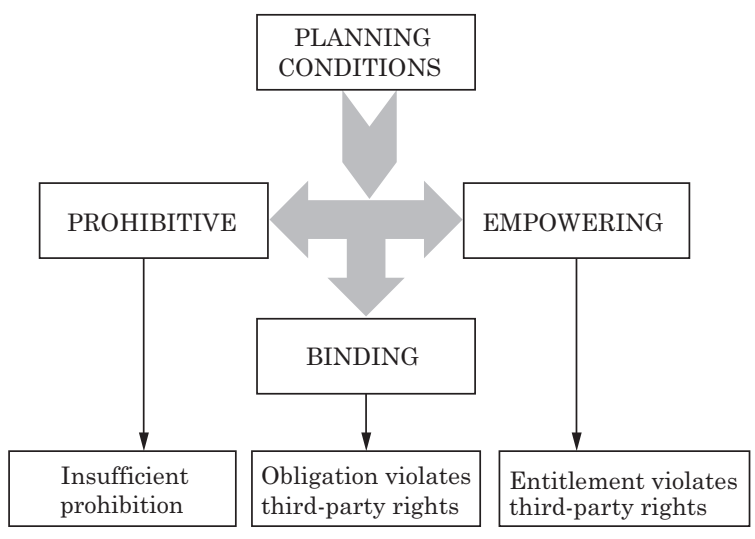

Figure 3. Classification of the planning conditions violating third-party rights

1. Prohibitive;

2. Binding;

3. Empowering.

All these types of planning conditions may infringe third-party rights. Prohibitive planning conditions may set insufficient prohibition. Planning conditions may prohibit construction works at a distance of, say, less than $10 \mathrm{~m}$ from a certain structure, while the legal norms would require a bigger distance.

Binding planning conditions may violate third-party rights in two ways:

1. A binding planning condition may lack scope. The originator of detailed plan, for instance, sets a provision by the planning conditions to ensure one room in an apartment of a neighbouring building has sufficient insolation, while the requirements of normative legal acts say insolation must be ensured in two rooms.

2. A binding planning condition may violate third-party rights directly. A case in point would be the originator of detailed plan charged to plan illegal solutions.

Empowering planning conditions violate third-party rights when they entitle originators of detailed plan to include solutions infringing a right of third parties. Such cases may be when third parties have their access to public roads cut off or restricted by solutions of detailed plans. 
In practice, a situation may happen when municipality's chief architect issues planning conditions which would violate third-party rights after implementation. Such conditions are also governed by normative legal acts and other territorial planning documents. All solutions violating third-party rights also violate the provisions set forth in normative legal acts.

The planning conditions which would violate third-party rights, therefore, can be viewed from different perspectives. They violate thirdparty rights, but, on the other hand, originators of the detailed plans must not comply with such provisions of planning conditions. The decision to issue such planning conditions is anyway illegal and can be contested as established by the Law on Administrative Proceedings of the Republic of Lithuania (2004).

The second stage of violations of thirdparty rights during the territorial planning is when the third parties become aware their rights have been violated. In order to defend your own violated rights it is necessary to know they have been violated. The issue of awareness about violation of rights in territorial planning is extremely important, but the violation becomes evident only when the solutions of the detailed planning are being implemented - i.e. the construction or preparation of the territory (cutting of trees, etc.) starts. As mentioned before, the main solutions of a construction investment project are approved during the detailed territorial planning. During detailed planning, violation of third party rights occurs when illegal solutions are set. Judicial practise includes quite a number of cases when administrative courts cancelled decisions approving detailed plans after the construction had already started. Such situations are related to the fact that the complainants learn about the preparation and approval of the detailed plan only when the construction process starts. In order to avoid such situations, the newest edition of the Law on Territorial Planning of the Republic of Lithuania (2004) specifically focuses on issues of public relations.

Third parties can learn about the process of territorial planning and about its solutions following the provisions of the Law on Territorial Planning of the Republic of Lithuania (2004) on transparency of territorial planning activities and the Regulations on Informing the General Public and Public Participation in the Territorial Planning Procedures of the Republic of Lithuania (2007) approved by the resolution No. 33-1190 of 21 March 2007 of the Government of the Republic of Lithuania.

In order to determine the right of third parties to be aware of the preparation procedure of detailed plans and their solutions, each public awareness-raising procedure must be discussed individually. Notably, the Regulations on Informing the General Public and Public Participation in the Territorial Planning Procedures of the Republic of Lithuania (2007) define the concept of the procedure ensuring publicity as one or several actions which must be taken by the organiser of planning or its authorised representative and are related to awareness raising among public and the involvement of public in the drafting of the territorial planning document, as well as to the opportunities for the public to submit suggestions on supplementing, alternatives or modification of the solutions specified in the territorial planning document.

Article 30 of the Law on Territorial Planning of the Republic of Lithuania (2004) sets detailed territorial planning as a public activity. The organisers of planning are responsible for procedures granting transparency of territorial planning.

Article 31 of the Law on Territorial Planning of the Republic of Lithuania (2004) sets the following procedures to inform the public about detailed territorial planning:

1. Municipalities and their executive organs must announce decisions on preparation of detailed plans in local press, in municipal websites and in neighbourhoods involved in the planning;

2. The organiser of detailed planning must inform in writing the managers and users of the adjacent land parcels of the beginning of preparation of territorial planning documents and the planning targets of the land parcel or a group of land parcels and must set up, nest to the 
planned territory, a plaque bearing the said information as prescribed by the rules regulating detailed planning;

3. The organisers of planning must announce about the prepared planning document of the municipality or its part, about the procedure of getting access to it or hearing, the place and time thereof, as well as the wards where the planned territory is, in the notice board and, in the event of detailed planning of the land parcel or group of land parcels, also in the notice board installed by the planned territory;

4. The public shall have the right of access to approved territorial planning document concepts, if prepared, also to the prepared and approved territorial planning documents, in the institution which was the organiser of the territorial planning; they shall be entitled to obtain copies of drawings and territorial planning documents or parts thereof for a fee established upon calculating the costs related to the preparation of these documents (copying, publishing, etc.);

5 . The organiser of planning must arrange public exposure of the prepared detailed plan. The public must be introduced to the prepared territorial planning documents by the organiser of planning or its authorised person during the consulting and public hearing: at least 20 business days must be assigned for getting access to the prepared detailed plans and at least 10 business day of the period must be assigned for public exposure;

6. The organisers of planning must arrange public discussions of the detailed plan.

These provisions of the Law on Territorial Planning of the Republic of Lithuania (2004) are explained in detail in the Regulations on Informing the General Public and Public Participation in the Territorial Planning Procedures (2007) (Mitkus and Šostak, 2008).

When solutions of detailed planning are declared illegal after the construction has already started, it may result in a huge loss for the investors. Therefore, all parties involved in territorial planning (the third parties as well) are interested to coordinate the solutions of the detailed planning and resolve all disputes as soon as possible.

When the third parties become aware of possible violations in time, it may result in a pre-trial defence and a compromise among all interested parties.

The Law on Administrative Proceedings of the Republic of Lithuania (2004) and the Law on Territorial Planning of the Republic of Lithuania (2004) set forth the procedure for pre-trial dispute hearing; each party concerned also has a right to plead to court as established by law in order to protect a violated or disputed right, or an interest protected by law (Mitkus and Šostak, 2008).

The actions of parties in a conflict situation determine either constructive or destructive course of the conflict scenario (see Figure 2). It is in the interest of both conflicting parties to settle all disputes as early as possible and thus avoid judicial litigation. A conflict reaching the court suggests that the parties failed to control the conflict and to collaborate - to make coordinated actions towards interrelated goals - thus the conflict took a destructive course. Both conflict parties suffer a loss at the initial stage. From now on the victory or defeat of each party will depend on the efforts of their lawyers, the decisions of judicial bodies, etc. The process has become uncontrollable.

To avoid a judicial dispute, practical use of the procedures ensuring publicity must be explained, because the mistakes made or problems unresolved at this phase may hurt implementation of a construction investment project. It is at this stage that the democratic and diplomatic approach of the organiser of planning nurtures the buds of collaboration with the public concerned. Proper use of publicity procedures presupposes successful implementation of a construction investment project. The public concerned also must take active part in the detailed territorial planning procedures by submitting written suggestions to the organiser of planning throughout the prepara- 
tion of territorial planning documents - before and during the public discussion (The Law on Territorial Planning of the Republic of Lithuania, 2004: Art. 32). The relation must be reciprocal, because no active involvement of the public concerned at this phase means that later it will not have any say in implementation of the solutions of the construction investment project.

In view of the complexity related to settlement of conflict situations, as well as the abundance of parties, information and data, the authors believe that an information system is necessary. The goal and purpose of the system is to accumulate, analyse and visualise data and processes. In their scientific publications, the scientists from a number of countries have noted the importance to display information visually (Gelernter, 2007). The system accumulates various types of data: numerical, textual, logic and graphic. The search and management of such data can be optimised with the help of visualisation methods.

Visualisation of information aims to present graphic information to the user and to facilitate the analysis of data when their amount and multidimensionality prevent proper assessment and increase the likelihood of errors. An information system which would accumulate detailed plans, legal documents and information about investors, third parties and stakeholder groups would help not only to analyse but also to update data. Visualisation methods would assist with proper interpretation of the search results and help avoid initial errors. For that purpose, a knowledge base, assessment criteria and solutions would be required.

\section{CONCLUSIONS}

It is in the interest of the conflicting parties to settle all disputes as early as possible and to avoid judicial litigation. A conflict reaching the court suggests that the parties failed to control the conflict and to collaborate - to make coordinated actions towards interrelated goals thus the conflict took a destructive course.
Handling of disputes related to violations of third-party rights might lead, and actually does lead, to huge losses incurred by both investors and third parties. To safeguard success of a construction investment project, all potential issues related to stakeholder groups must be determined and sorted out as early as the phase of detailed territorial planning. Open and patient attempts to determine the needs of the public concerned are necessary. Collaboration is required: with open dialogue and negotiations, if necessary. Thus the conflicting parties must admit and understand different, often opposite, needs and interests and to make joint efforts to find possible solutions.

As a means to prevent judicial disputes and to go through with construction investment projects successfully, the article analyses and explains the procedures ensuring publicity in Lithuania, because the mistakes made at this phase may hurt implementation of a construction investment project. It is at this phase that the democratic approach of the organiser of planning nurtures the buds of collaboration with the public concerned. Timely awareness of possible violation of third-party rights means they can be defended out-of-court by seeking a compromise acceptable to all stakeholders.

In view of the complexity related to settlement of conflict situations, as well as the abundance of parties, information and data, the authors believe that an information system must be developed in the course of future research. An information system with systematic presentation of all accumulated information about the preparation of detailed plans, legal documents, investors, third parties and stakeholder groups would help not only to analyse but also to update data.

\section{REFERENCES}

Antuchevičienė, J., Zavadskas, E. K. and Zakarevičius, A. (2010) Multiple criteria construction management decisions considering relations between criteria, Technological and Economic Development of Economy, 16(1), pp. 109-125. http://dx.doi.org/10.3846/ tede. 2010.07 
Banaitienè, N., Banaitis, A. and Norkus, A. (2011) Risk management in projects: peculiarities of Lithuanian construction companies, International Journal of Strategic Property Management, 15(1), pp. 60-73. http://dx.doi.org/10.3846/1648715X.2011.568675

Banaitis, A. and Banaitienè, N. (2007) Development of a rational housing model: the Lithuanian case, International Journal of Environment and Pollution, 30(3/4), pp. 430-442. http://dx.doi.org/10.1504/ IJEP.2007.014820

Bardauskienè, D. (2007) Ekspertinių vertinimu taikymas rengiant miesto bendraji planą [The expert's estimates application in the preparation of city general plan], Technological and Economic Development of Economy, 13(3), pp. 223-236. (In Lithuanian) http:// dx.doi.org/10.1080/13928619.2007.9637804

Blaszczyk, T. and Nowak, M. (2009) The time-cost tradeoff analysis in construction project using computer simulation and interactive procedure, Technological and Economic Development of Economy, 15(4), pp. 523-539. http://dx.doi.org/10.3846/13928619.2009.15.523-539

Burinskienè, M. (2009) Editorial. New methodology for sustainable development towards sustainable transportation system, Technological and Economic Development of Economy, 15(1), pp. 5-9. http://dx.doi. org/10.3846/1392-8619.2009.15.5-9

Burinskienè, M. and Rudzkienè, V. (2009) Future insights, scenarios and expert method application in sustainable territorial planning, Technological and Economic Development of Economy, 15(1), pp. 10-25. http:// dx.doi.org/10.3846/1392-8619.2009.15.10-25

Chamodrakas, I., Leftheriotis, I. and Martakos, D. (2011) In-depth analysis and simulation study of an innovative fuzzy approach for ranking alternatives in multiple attribute decision making problems based on TOPSIS, Applied Soft Computing, 11(1), pp. 900907. http://dx.doi.org/10.1016/j.asoc.2010.01.010

Chou, J. S. and Lin, C. (2013) Predicting disputes in public-private partnership projects: classification and ensemble models, Journal of Computing in Civil Engineering-ASCE, 27(1), pp. 51-60. http://dx.doi. org/10.1061/(ASCE)CP.1943-5487.0000197

Deutsch, M. (1994) Constructive conflict management for the world today, International Journal of Conflict Management, 5(2), pp. 111-129. http://dx.doi. org/10.1108/eb022738

Desierto, D. A. (2013) Conflict of treaties, interpretation, and decision-making on human rights and investment during economic crises, Transnational Dispute Management, 1, Available at: www.transnationaldispute-management.com/article.asp?key=1930

Dixon, W. J. (1996) Third-party techniques for preventing conflict escalation and promoting peaceful settlement, International Organization, 50(4), pp. 653-681. http://dx.doi.org/10.1017/S0020818300033543

Erdis, E. (2013) The effect of current public procurement law on duration and cost of construction projects in Turkey, Journal of Civil Engineering and Management, 19(1), pp. 121-135. http://dx.doi.org/10.3846/1 3923730.2012 .746238
Gelernter, J. (2007) Visual classification with information visualization (infoviz) for digital library collections, Knowledge Organization, 34(3), pp. 128-143.

Jakaitis, J., Paliulis, N. and Jakaitis, K. (2009) Aspects of the national urban policy management under conditions of integrated planning, Technological and Economic Development of Economy, 15(1), pp. 26-38. http://dx.doi.org/10.3846/1392-8619.2009.15.26-38

Kaklauskas, A., Zavadskas, E. K., Vainiūnas, P., Jonaitis, V. and Stragys, V. (2007) Lietuvos statybu 20072030 vizija ir strategija. Gyvenimo kokybè [A vision and strategy for Lithuanian construction 2007-2030. Quality of life]. Lietuvos nacionalinè statybu technologiju platforma, pp. 30-38 (in Lithuanian).

Kaklauskas, A., Zavadskas, E. K. and Šaparauskas, J. (2009) Conceptual modelling of sustainable Vilnius development, Technological and Economic Development of Economy, 15(1), pp. 154-177. http://dx.doi. org/10.3846/1392-8619.2009.15.154-177

Kahraman, C. and Kaya, I. (2010) Investment analyses using fuzzy probability concept, Technological and Economic Development of Economy, 16(1), pp. 43-57. http://dx.doi.org/10.3846/tede.2010.03

Keršulienè, V., Zavadskas, E. K. and Turskis, Z. (2010) Selection of rational dispute resolution method by applying new step-wise weight assessment ratio analysis (Swara), Journal of Business Economics and Management, 11(2), pp. 243-258. http://dx.doi. org/10.3846/jbem.2010.12

Lakis, J. (2008) Konfliktu sprendimas ir valdymas [Conflict resolution and management], pp. 12-39, 93-100. Vilnius: Mykolo Romerio universitetas. ISBN 9789955-19-082-0 (In Lithuanian).

Lin, M. C., Tserng, H. P., Ho, S. P. and Yuong, D. L. (2011) Developing a construction-duration model based on a historical dataset for building project, Journal of Civil Engineering and Management, 17(4), pp. 529539. http://dx.doi.org/10.3846/13923730.2011.625641

Lopes, J., Nunes, A. and Balsa, C. (2011) The long-run relationship between the construction sector and the national economy in Cape Verde, International Journal of Strategic Property Management, 15(1), pp. 4859. http://dx.doi.org/10.3846/1648715X.2011.565909

McDonald, S., Malys, N. and Malienè, V. (2009) Urban regeneration for sustainable communities: a case study, Technological and Economic Development of Econo$m y, 15(1)$, pp. 49-59. http://dx.doi.org/10.3846/13928619.2009.15.49-59

Medineckiene, M., Turskis, Z. and Zavadskas, E. K. (2010) Sustainable construction taking into account the building impact on the environment, Journal of Environmental Engineering and Landscape Management, 18(2), pp. 118-127. http://dx.doi.org/10.3846/ jeelm.2010.14

Mitkus, S. and Šostak, O. R. (2008) Modelling the process for defence of third party rights infringed while implementing construction investment projects, Technological and Economic Development of Economy, 14(2), pp. 208-223. http://dx.doi.org/10.3846/13928619.2008.14.208-223 
Park, M., Chu, Y., Lee, H. S. and Kim, W. (2009) Evaluation methods for construction projects, Journal of Civil Engineering and Management, 15(4), pp. 349-359. http://dx.doi.org/10.3846/1392-3730.2009.15.349-359

Pinter, U. and Pšunder, I. (2013) Evaluating construction project success with use of the M-TOPSIS method, Journal of Civil Engineering and Management, 19(1), pp. 16-23. http://dx.doi.org/10.3846/13923730 .2012 .734849

Ramirez, R. (1999) Stakeholder analysis and conflict management. Chapter 5. In: Buckles, D. (Ed.), Cultivating peace. Conflict and collaboration in natural resource management, International Development Research Centre, pp. 101-126.

Regulations on Informing the General Public and Public Participation in the Territorial Planning Procedures of the Republic of Lithuania (2007) Valstybes žinios, 2007-03-21, Nr. 33-1190. (In Lithuanian)

Smyth, L. F. (2002) Identity-based conflicts: a systemic approach evaluation project, Negotiation Journal, 18(2), pp. 147-161. http://dx.doi. org/10.1023/A:1016196519460

Šostak, O. R. and Vakrinienè, S. (2011) Mathematical modelling of dispute proceedings between investors and third parties on allegedly violated third-party rights, Journal of Civil Engineering and Management, 17(1), pp. 126-136. http://dx.doi.org/10.3846/1 3923730.2011 .560628

Šstak, O. R. (2011) Planning development of construction by taking into account interests of the third parties. Ph.D. thesis, Vilnius Gediminas Technical University, Vilnius: Technika. ISBN 978-9955-28-862-6

The Supreme Administrative Court of Lithuania (2005) The judgement of the Supreme Administrative Court of Lithuania of 21 January 2005 in the administrative case the Applicants the Homeowner Association No. 968 vs. the Administration of Vilnius City Municipality, No. A ${ }^{14}-54-05$. [Online]. The Supreme Administrative Court of Lithuania. Available at: http:// www.lvat.lt/Default.aspx?item $=$ nutart\&lang=1. [accessed 21 September 2009] (in Lithuanian).

The Supreme Administrative Court of Lithuania (2006) The resolution of the Supreme Administrative Court of Lithuania of 20 February 2006 in the administrative case the Applicants A. S., B. S. and T. Z. vs. the Administration of Vilnius City Municipality, No. $\mathrm{A}^{11}$-792/2006] [Online]. The Supreme Administrative Court of Lithuania. Available at: http://www.lvat.lt/ Default.aspx?item=nutart\&lang=1. [accessed $25 \mathrm{Sep}$ tember 2007] (in Lithuanian).

The Supreme Administrative Court of Lithuania (2007a) The judgement of the Supreme Administrative Court of Lithuania of 19 January 2007 in the administrative case The Applicant T. Z. vs. the Administration of Vilnius City Municipality, No. A ${ }^{3}-64-$ 07. [Online]. The Supreme Administrative Court of Lithuania. Available at: http://www.lvat.lt/Default. aspx?item=nutart\&lang=1. [accessed 25 September 2007] (in Lithuanian).

The Supreme Administrative Court of Lithuania (2007b) The judgement of the Supreme Administrative Court of Lithuania of 26 January 2007 in the administrative case The Applicant O. Š., L. K vs. the Administration of Vilnius City Municipality, No. A14-110 07. [Online]. The Supreme Administrative Court of Lithuania. Available at: http://www.lvat.lt/Default. aspx?item=nutart\&lang=1. [accessed 25 September 2007] (in Lithuanian).

The Law on Administrative Proceedings of the Republic of Lithuania (2004) Vilnius, Valstybes žinios, 200010 11, Nr. 85-2566 (in Lithuanian).

The Law on Territorial Planning of the Republic of Lithuania (2004) Vilnius, Valstybès žinios, 200402 07, Nr. 21-617. (In Lithuanian)

Witt, E. and Liias, R. (2011) Comparing risk transfers under different procurement arrangements, International Journal of Strategic Property Management, 15(2), pp. 173-188. http://dx.doi.org/10.3846/164871 5X.2011.582750

Xu, Y., Lu, Y., Chan, A. P. C. and Skibniewski, M. J. (2012) A computerized risk evaluation model for public-private partnership (PPP) projects and its application, International Journal of Strategic Property Management, 16(3), pp. 277-297. http://dx.doi.org/10. 3846/1648715X.2012.686928

Yang, J., Shen, G. Q., Ho, M., Drew, D. S. and Chan, A. P. C. (2009) Exploring critical success factors for stakeholder management in construction projects, Journal of Civil Engineering and Management, 15(4), pp. 337-348. http://dx.doi.org/10.3846/13923730.2009.15.337-348

Yeh, K. C., Tsai, M. H. and Kang, S. C. (2012) On-site building information retrieval by using projectionbased augmented reality, Journal of Computing in Civil Engineering-ASCE, 26(3), pp. 342-355. http:// dx.doi.org/10.1061/(ASCE)CP.1943-5487.0000156

Zavadskas, E. K., Kaklauskas, A., Turskis, Z. and Kalibatas, D. (2009) An approach to multi-attribute assessment of indoor environment before and after refurbishment of dwellings, Journal of Environmental Engineering and Landscape Management, 17(1), pp. 5-11. http://dx.doi.org/10.3846/16486897.2009.17.5-11

Zavadskas, E. K. and Kaklauskas, A. (2008) The model for Lithuanian construction industry development, Transformations in Business \& Economics, 7(1), pp. $152-168$.

Zavadskas, E. K., Turskis, Z. and Tamošaitienè, J. (2010a) Risk assessment of construction projects, Journal of Civil Engineering and Management, 16(1), pp. 33-46. http://dx.doi.org/10.3846/jcem.2010.03

Zavadskas, E. K., Kaklauskas, A. and Banaitis, A. (2010b) Application of e-technologies for regional development: the case of Vilnius city, Journal of Business Economics and Management, 11(3), pp. 415-427. http://dx.doi.org/10.3846/jbem.2010.20

Zavadskas, E. K. and Turskis, Z. (2011) Multiple criteria decision making (MCDM) methods in economics: an overview, Technological and Economic Development of Economy, 17(2), pp. 397-427. http://dx.doi.org/10. $3846 / 20294913.2011 .593291$ 